\title{
CONCENTRATION AND SIZE OF AIRBORNE PARTICULATES IN WOODWORKING SHOPS ${ }^{1}$
} Renan Pereira Barbosa ${ }^{2}$, Nilton Cesar Fiedler ${ }^{3 *}$, José Reinaldo Moreira Silva $^{4}$, Amaury Paulo de Souza $^{5}$
Luciano José Minette ${ }^{6}$ and Michel Picanço Oliveira ${ }^{7}$

\footnotetext{
${ }^{1}$ Received on 17.08.2016 accepted for publication on 10.08.2017.

${ }^{2}$ Universidade Federal de Viçosa, Graduado em Ciência Florestal, Viçosa, MG - Brasil. E-mail: <renanpb_mg@hotmail.com>.

${ }^{3}$ Universidade Federal do Espírito Santo, Departamento de Engenharia Florestal, Jerônimo Monteiro, ES-Brasil. E-mail: $<$ fiedler@pq.cnpq.br>.

${ }^{4}$ Universidade Federal de Lavras, Departamento de Ciências Florestais, Lavras, MG - Brasil . E-mail: <reinaldo@ufla.br>.

${ }^{5}$ Universidade Federal de Viçosa,Departamento de Engenharia Florestal,, Viçosa, MG - Brasil. E-mail: <amaury@ufv.br>.

${ }^{6}$ Universidade Federal de Viçosa,Departamento de Engenharia de Produção e Mecânica, Viçosa, MG - Brasil. E-mail: <minette@ufv.br>.

${ }^{7}$ Universidade Estadual do Norte Fluminense Darcy Ribeiro, Centro de Ciências e Tecnologias, RJ - Brasil. E-mail: $<$ michelpicanco@gmail.com>.

*Corresponding author.
}

\begin{abstract}
Wood secondary processing operations generate large amounts of airborne particulates. Inhalation of this material can lead to the development of work-related respiratory diseases. The Brazilian legislation does not define threshold limit values for airborne wood particles, and local studies are required to provide a technical basis for establishing these limits by regulation. This study aimed to determine the concentration and size of airborne wood particles of Eucalyptus spp. in woodworking shops. Analysis of the concentration of airborne particles was carried out using a gravimetric sampling pump and collector filters. The size of airborne particles was determined using microscope slides and an optical microscope coupled to an image capture system. Air samples were collected near different machines (belt sander, table saw, and band saw) at five woodworking shops located in the state of Espírito Santo, Brazil. Of the three machines, the belt sander produced the most harmful type of particulate matter: the small size of these particles allows their deposition deep into the respiratory tract. Particulate matter was above the threshold limit value established by international standards. To prevent the risk of severe health effects, there is an urgent and imperative need to reduce worker exposure levels (by the use of collective and personal protective equipment) as well as for the implementation of specific regulations that define particulate exposure limits for the wood sector in Brazil.
\end{abstract}

Keywords: Forest ergonomics; Occupational safety; Joinery.

\section{CONCENTRAÇÃO E DIMENSÃO DE PARTICULADOS SUSPENSOS NO AR EM UNIDADES DE PROCESSAMENTO MECÂNICO DE MADEIRA}

\begin{abstract}
RESUMO - As operações de processamento secundário de madeira geram grande quantidade de particulados suspensos no ar. A inalação desse material pode estimular o aparecimento de doenças respiratórias nos trabalhadores expostos nestes ambientes de trabalho. No entanto, no Brasil ainda não há um limite de tolerância definido para partículas de madeira suspensas, necessitando de estudos para embasamento técnico e definição desse limite. Objetivou-se mensurar a concentração e dimensão das partículas de madeira de Eucalyptus spp. suspensas no ar em marcenarias. A análise da concentração das partículas suspensas foi desenvolvida pela utilização de bomba gravimétrica e coletores com filtros. Para dimensionar as partículas suspensas no ar usou-se lâminas, microscópio e fotografias. Os dados foram coletados na lixadeira, serra circular e serra fita, em cinco marcenarias semelhantes, no estado do Espírito Santo. Os particulados mais danosos à saúde humana foram provenientes da lixadeira, que pela pequena dimensão facilitam a deposição nas partes mais prejudiciais ao trato respiratório humano. Constatou-se que as concentrações de partículas suspensas encontradas estão acima dos limites
\end{abstract}


recomendados pelas normas internacionais. Diante do risco de danos severos a saúde, há a necessidade urgente e imprescindível de implementação de medidas para redução dos níveis de exposição (EPC e EPI), bem como a implementação de normatização específica com limites de exposição máximo definidos para o setor no Brasil.

Palavras-Chave: Ergonomia florestal, segurança no trabalho, marcenarias.

\section{INTRODUCTION}

Occupational health and safety is an issue of utmost importance for enterprises. Worker exposure to hazardous environments may result in irreversible health effects that can lead to occupational diseases. Despite Brazil's strict regulatory policies and occupational safety standards, the number of work accidents has increased in recent years (Mendes et al., 2017). Reducing-or, ideally, completely preventing - damages caused by long work hours spent in unsuitable environments should be the primary goal of occupational hygiene.

In the wood furniture industry, workers are frequently exposed to inadequate conditions, especially in smallsized enterprises, where the availability of safe, ergonomic, and high-tech machines and tools is limited (Tremblay and Badri, 2018; Top et al., 2016).

Different types of particles are present in these workplaces, some of which may be harmful to workers. According to the Jorge Duprat Figueiredo Foundation of Safety and Occupational Health (Fundação Jorge Duprat e Figueiredo, 1994), respiratory protection programs must be implemented at work environments with high concentrations of dust. According to Pavlovska et al. (2016), there is a large number of airborne nano and microparticles in woodworking industries, and these particulates may pose risks to human health depending on their composition.

The occupational hazards of dust exposure may vary from an initial and simple respiratory irritation to serious diseases, such as pneumoconiosis and cancer. The wood industry uses several species of wood that can cause inflammation, allergies, and pharyngitis, leading to work-related health problems (Moura et al., 1993).

Excessive exposure to wood dust has also been linked to the development of other respiratory conditions: lower airway obstruction and reactive upper airway disease (Enarson and Chan-Yeung, 1990).

Inhalation is the most common route of entry of dust into the body. Excessive inhalation of dust can cause various health effects, as it overloads the

Revista Árvore. 2018;42(1):e420109 mechanisms used by the respiratory system to clean and protect itself. The severity of these effects depends on different factors, such as the chemical composition of dust, the concentration of particles in suspension in the air, their place of deposition in the respiratory tract, and duration of exposure (Santos, 2001).

According to Fundação Jorge Duprat e Figueiredo (2007), particles can be grouped according to their size into three categories of high relevance to occupational hygiene because of their site of deposition: inhalable particles $(<100 \mathrm{im})$, which can penetrate the nose and mouth; thoracic particles, $(<25 \mathrm{im})$, which can penetrate into the larynx; and respirable particles ( $<10 \mathrm{im})$, which can penetrate alveoli. Particles deposited in the lower airways or in the lungs pose a greater health risk than particles deposited in the upper airways.

Dust deposited in the lungs may induce mucus hypersecretion and hypertrophy of mucus-secreting cells, macrophage recruitment into the lungs, inflammatory reactions, fibrosis, and cancer (Bon and Santos, 2003).

The purpose of this study was to determine the concentration and size of airborne particulates in woodworking shops and evaluate the occupational hazards of particulate deposition in the respiratory tract of workers. As the Brazilian legislation does not define threshold limit values for exposure to particulates, this study also aimed to develop a scientific basis for establishing threshold limit values for airborne wood particles so as to minimize particle inhalation and thus avoid the development of respiratory diseases.

\section{MATERIALAND METHODS}

The study was carried out in five woodworking shops located in the municipalities of Jerônimo Monteiro, Rio Novo do Sul, and Iconha, in the state of Espírito Santo, Brazil. The woodworking shops had similar characteristics regarding machine models and tools, work hours, production processes, and absence of exhaust fans. The shops had no ventilation system, and few workers used respiratory protective equipment. 
The study was developed following basic precepts defined by the Brazilian Regulatory Standards NR 9, NR 15, and NR 17 (Segurança e Medicina do Trabalho, 2015), Fundacentro Occupational Hygiene Standards (NHOs), National Institute for Occupational Safety and Health (NIOSH), and American Conference of Governmental Industrial Hygienists (ACGIH).

Particulates were collected, quantified, and measured to allow a comparative evaluation of the characteristics of particles produced by the processing of materials on a belt sander, table saw, and band saw (Table 1).

Sample collection was carried out on workdays between $9 \mathrm{~h} 00$ and 16h00, from January to May 2015. Temperature, ventilation, and humidity were monitored to ensure that samplings were performed under similar conditions.

\subsection{Determination of dust concentration}

Particulates were collected in the woodworking shops during the execution of usual tasks by workers. The Fundacentro standards NHO 03 (Fundação Jorge Duprat e Figueiredo, 2001) and NHO 08 (Fundação Jorge Duprat e Figueiredo, 2007) were used to evaluate the concentration of airborne dust particles. To complement the NHO procedures, calibration and collection time parameters defined by NIOSH were also employed.

\subsection{Collection of dust samples}

A gravimetric sampling pump was used to collect dust samples. The contaminated air was sucked by the pump, and particles were filtered and retained by a polyvinyl chloride (PVC) membrane. The mass of the PVC membrane filters was measured on a precision scale before and after the collection of airborne particulates. Particulate mass was calculated as the difference between final and initial filter mass. During sampling, workers performed routine tasks under their usual work conditions. Three samples were collected per woodworking shop, totaling fifteen samples. Prior to particulate sampling, temperature and relative humidity measurements were taken. Samples were collected only on days with similar temperature and humidity conditions.

After sample collection, the collector filters were sent to the laboratory Solutech Chemical Analyses, where the concentration of airborne wood particles was determined. The concentration of each sample and the mean concentration of airborne wood particles were calculated using the collected air volume and the mass of filtered materials.
Table 1 - Description of the machines evaluated in the woodworking shops.

Tabela 1 - Descrição das máquinas avaliadas durante o processo de usinagem da madeira.

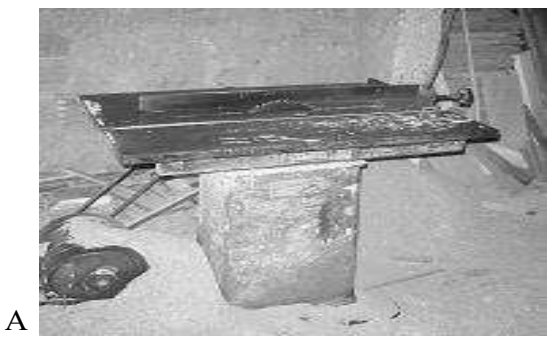

Table saw - has a toothed, circular saw blade to cut wood and wood products along a straight line.

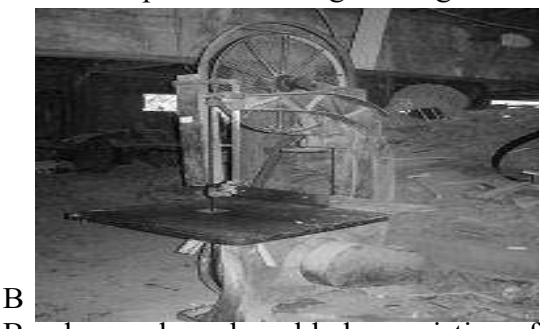

Band saw - has a long blade consisting of a continuous band of toothed steel and can be used for making straight or curved cuts.

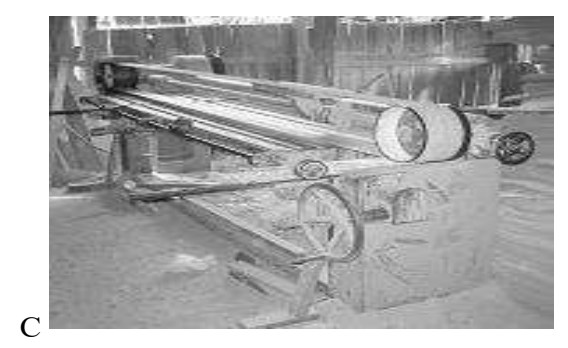

Belt sander - used for shaping and finishing flat or curved surfaces. It can improve surface finish by removing marks left by cutting tools

\subsection{Size analysis of airborne dust particles}

For particle size analysis, dust residues retained on the PVC membranes were measured according to the method proposed by Teixeira (2013). Briefly, particles were transferred onto glass slides with glycerin and water $(1: 1)$.

Three slides were prepared for each machine sampled. Each slide was photographed five times, totaling 225 images. Subsequently, images were analyzed and measured on a microscope coupled to an image capture system.

Revista Árvore. 2018;42(1):e420109 
Images were analyzed using the Image-Pro Plus software at $40 \times$ magnification. For each image, 10 randomly selected wood particles were measured. The site of particle deposition in the body was predicted based on particle size.

A randomized design was used for the statistical analysis of particle concentration and size, comprising three treatments and five repetitions, in which the former represents the machines and the latter, the woodworking shops. Data were analyzed statistically by analysis of variance. When significant results were obtained, means were compared by Tukey's test at the 5\% significance level.

\section{RESULTS}

\subsection{Concentration of airborne particulates}

Considering the threshold limit value of particulate concentration defined by the American Conference of Governmental Industrial Hygienists (2012), all woodworking shops had concentrations above the limit $\left(0.88 \mathrm{mg} \mathrm{m}^{-3}\right)$, exposing workers to occupational hazards that could lead to respiratory diseases. The machine that had the highest production of particulates was the belt sander (a mean particulate concentration of $\left.3.46 \mathrm{mg} \mathrm{m}^{-3}\right)$, followed by the table saw $(2.00 \mathrm{mg}$ $\left.\mathrm{m}^{-3}\right)$ and the band saw $\left(0.98 \mathrm{mg} \mathrm{m}^{-3}\right)$. The mean particulate concentration in each woodworking shop is shown in Figure 1.

The particulate concentrations produced by the belt sander and the table saw did not differ statistically at the $5 \%$ probability level by Tukey's test. The mean particulate concentrations produced by the table saw and

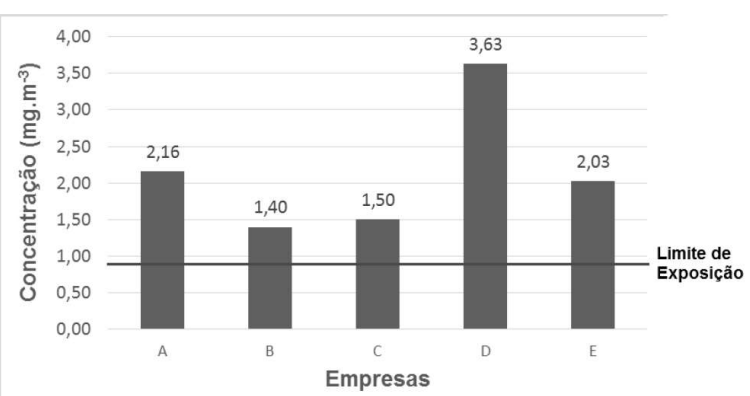

Figure 1 - Mean concentration of airborne particulates per woodworking shop.

Figura 1 - Concentração média de particulados dispersos no ar por empresa.
Table 2 - Mean size of airborne wood particles per machine and per woodworking shop.

Tabela 2 -Dimensão média das partículas de madeira suspensas no ar por máquina e empresa.

\begin{tabular}{lccccc}
\hline \multirow{2}{*}{ Machine $\begin{array}{c}\text { Woodworking } \\
\text { shop }\end{array}$} & \multicolumn{3}{c}{$\begin{array}{c}\text { Sample } \\
\text { (particle size in } \mu \mathrm{m})\end{array}$} & $\begin{array}{c}\text { Mean } \\
\text { particle } \\
\text { size }(\mu \mathrm{m})\end{array}$ \\
\cline { 3 - 5 } & & \multicolumn{4}{c}{2} \\
\hline Belt sander & $\mathrm{A}$ & 16.35 & 18.15 & 15.91 & $16.80 \mathrm{~b}$ \\
& $\mathrm{~B}$ & 17.58 & 20.55 & 18.57 & $18.90 \mathrm{ab}$ \\
& $\mathrm{C}$ & 25.30 & 28.83 & 25.01 & $26.38 \mathrm{a}$ \\
& $\mathrm{D}$ & 21.87 & 14.45 & 16.51 & $17.61 \mathrm{ab}$ \\
& $\mathrm{E}$ & 17.05 & 20.78 & 23.47 & $20.43 \mathrm{ab}$ \\
\hline Table saw & $\mathrm{A}$ & 27.39 & 33.40 & 29.67 & $30.15 \mathrm{a}$ \\
& $\mathrm{B}$ & 22.72 & 34.65 & 40.12 & $32.50 \mathrm{a}$ \\
& $\mathrm{C}$ & 33.25 & 28.22 & 35.83 & $32.43 \mathrm{a}$ \\
& $\mathrm{D}$ & 28.56 & 24.46 & 30.30 & $27.77 \mathrm{a}$ \\
& $\mathrm{E}$ & 31.67 & 28.92 & 28.63 & $29.74 \mathrm{a}$ \\
\hline Band saw & $\mathrm{A}$ & 21.55 & 23.96 & 20.75 & $22.08 \mathrm{~b}$ \\
& $\mathrm{~B}$ & 26.88 & 25.55 & 22.32 & $24.91 \mathrm{~b}$ \\
& $\mathrm{C}$ & 35.64 & 39.81 & 34.83 & $36.76 \mathrm{a}$ \\
& $\mathrm{D}$ & 31.48 & 34.86 & 33.13 & $33.16 \mathrm{a}$ \\
& $\mathrm{E}$ & 20.03 & 21.69 & 21.91 & $21.21 \mathrm{~b}$ \\
\hline
\end{tabular}

the band saw were statistically equal at the $90 \%$ probability level. The difference between particulate concentration produced by the belt sander and the band saw was statistically significant.

\subsection{Particulate size}

The results of particle size were characterized in two manners: mean size and site of deposition in the respiratory tract. The mean particulate size is shown in Table 2. Samples were analyzed per machine and per shop.

Table 3 shows the mean, maximum, and minimum sizes obtained in the analysis. Values are presented according to the machine.

The regions of particle deposition in the respiratory tract of workers exposed to wood processing environments are shown in Table 4. Data were grouped by machine.

Table 3 - Mean, maximum, and minimum particle size (PS) per machine.

Tabela 3 - Dimensões média, máxima e mínima das partículas

\begin{tabular}{lccc}
\multicolumn{4}{c}{ de acordo com a máquina avaliada. } \\
\hline Machine & $\begin{array}{c}\text { Mean } \\
\text { PS }(\mu \mathrm{m})\end{array}$ & $\begin{array}{c}\text { Maximum } \\
\text { PS }(\mu \mathrm{m})\end{array}$ & $\begin{array}{c}\text { Minimum } \\
\text { PS }(\mu \mathrm{m})\end{array}$ \\
\hline Belt sander & 18.57 & 144.27 & 1.40 \\
Table saw & 29.67 & 211.51 & 1.90 \\
Band saw & 25.55 & 152.98 & 1.25 \\
\hline
\end{tabular}

Revista Árvore. 2018;42(1):e420109 
Table 4 - Predicted pattern of particle deposition in the respiratory tract of operators per machine.

Tabela 4-Local de deposição das partículas no trato respiratório do operador por máquina.

\begin{tabular}{lccc}
\hline Particle & Belt sander & Table saw & Band saw \\
\hline Respirable, $<10 \mu \mathrm{m}$ & & & \\
Observed (\%) & 31.43 & 18.57 & 22.71 \\
Accumulated (\%) & 31.43 & 18.57 & 22.71 \\
\hline Thoracic, $<25 \mu \mathrm{m}$ & & & \\
Observed (\%) & 27.71 & 21.14 & 24.29 \\
Accumulated (\%) & 59.14 & 39.71 & 47.00 \\
\hline Inhalable, $<100 \mu \mathrm{m}$ & & & \\
Observed (\%) & 38.71 & 55.86 & 51.00 \\
Accumulated (\%) & 97.86 & 95.57 & 98.00 \\
\hline Not inhalable, $>100 \mu \mathrm{m}$ & & & \\
Observed (\%) & 2.14 & 4.43 & 2.00 \\
Accumulated (\%) & 100.00 & 100.00 & 100.00 \\
\hline
\end{tabular}

\section{DISCUSSION}

Wood dust was identified in all work environments of the five companies, on floors, walls, and machines, giving the impression of poorly maintained and untidy facilities.

No statistical difference was found among the mean sizes of particles produced by table saws of different woodworking enterprises. Particles generated by this machine ranged from 27.77 to $32.50 \mathrm{ìm}$. The size of particles produced by band saws of different enterprises had the greatest variation. Moreover, there was a great variation in particle size regardless of the concentration of particulates in each workplace, as has been reported by other authors (Verma et al., 2007; Harper et al., 2004; Tatum et al., 2001; Hinds, 1988).

Particle size determines the site of deposition within the respiratory tract; the smaller the particle, the more harmful it is to the respiratory system, as it may eventually reach the pulmonary alveoli. Excessive particulate deposition can lead to the development of occupational diseases, such as lower airway infections.

Comparative analysis showed that the belt sander had the worst results among the machines, followed by the band saw and the table saw. The belt sander produced the highest concentration of particulates with the lowest mean particle size. Workers who operate this machine are exposed to the highest level of hazardous residues. The band saw produced larger particles and lower particulate concentration than the belt sander; the larger the particles, the shorter the time they stay airborne. The table saw produced the lowest concentration of airborne wood-dust particles, which was close to the threshold limit value defined by international standards. In addition, the table saw produced the largest particles, which explains their low concentration in the air.

The larger the particulate, the more rapidly it falls to the ground, which is a positive aspect regarding worker exposure to occupational respiratory hazards. In this regard, there is an urgent need for the installation of exhaust systems in woodworking environments and the mandatory use of respiratory protective equipment for workers, especially for belt sander operators.

\section{CONCLUSIONS}

Dust concentration in all evaluated workstations exceeded the maximum acceptable value $\left(0.88 \mathrm{mg} \mathrm{m}^{-3}\right)$. By the belt sander, the mean particulate concentration was $3.46 \mathrm{mg} \mathrm{m}^{-3}$; by the table saw, $2.00 \mathrm{mg} \mathrm{m}^{-3}$; and by the band saw, $0.98 \mathrm{mg} \mathrm{m}^{-3}$.

The belt sander was the most hazardous machine to worker health regarding particulate inhalation, as it dispersed the smallest particles.

There was great variability in the size and shape of Eucalyptus spp. airborne particles after mechanical processing. Particle sizes of 1.25-211.51 ìm were identified. Particles smaller than 10.00 ìm are the most harmful to human health, as they deposit in alveoli and can cause diverse respiratory problems.

In order to operate within the legal framework on occupational safety, we suggest the adoption of a threshold limit value for particulates of $1.00 \mathrm{mg} \mathrm{m} \mathrm{m}^{\prime 3}$ in Brazil.

\section{REFERENCES}

American Conference of Governmental Industrial Hygienists. 2012 TLVs and BEIs handbook. Cincinnati: ACGIH; 2012. 43 p.

Bon AMT, Santos AMA. Sílica. São Paulo: Fundacentro; 2003. 54 p.

Enarson DA, Chan-Yeung M. Characterization of health effects of wood dust exposures. Am J Ind Med. 1990;17(1):33-8. http://dx.doi.org/10.1002/ ajim.4700170107. PMid:2407114. 
Fundação Jorge Duprat e Figueiredo. Ministério do Trabalho e Emprego. Programa de proteção respiratória: recomendações, seleção e uso de respiradores. São Paulo: Fundacentro; 1994.

Fundação Jorge Duprat e Figueiredo. Ministério do Trabalho e Emprego. Norma de Higiene Ocupacional 03: método de ensaio: análise gravimétrica de aerodispersóides sólidos coletados sobre filtros de membranas. São Paulo: Fundacentro; 2001.

Fundação Jorge Duprat e Figueiredo. Ministério do Trabalho e Emprego. Norma de Higiene Ocupacional 08: procedimento técnico: coleta de material particulado sólido suspenso no ar de ambientes de trabalho. São Paulo: Fundacentro; 2007.

Harper M, Akbar MZ, Andrew ME. Comparison of wood-dust aerosol size-distributions collected by air samplers. J Environ Monit. 2004 Dec;6(1):1822. http://dx.doi.org/10.1039/b312883k. PMid:14737465.

Hinds WC. Basis for particle size-selective sampling for wood dust. Appl Ind Hyg. 1988;3:6772.

Lippmann M. Size-selective health hazard samplig. In: Cohen BS, McCammon CS, editors. Air sampling instruments for evaluation of atmospheric contaminants. Cincinnati: ACGIH; 1999.

Mendes L, Santos HB, Ichikawa EY. Health and safety at work: analysis from the brazilian documentary. Saf Health Work. 2017;8(4):347-55. http://dx.doi.org/10.1016/j.shaw.2017.01.003. PMid:29276633.

Moura CO, Wolter Filho W, Absy ML. Alergias causadas por algumas espécies madeireiras da Amazônia. In: Ferreira EJ, Santos GM, Leão ELM, Oliveira LA, editors. Bases científicas para estratégias de preservação e desenvolvimento da Amazônia. Manaus: INPA; 1993. p. 89-106.
Pavlovska I, Martinsone Z, Vanadzins I, Martinsone I, Seile A, Sudmalis P. Occupational exposure parameters for characterization of nanoparticulate matter toxicity: metal versus wood processing. Process Saf Environ Prot. 2016;102:230-7. http://dx.doi.org/10.1016/ j.psep.2016.03.018.

Santos AMA. O tamanho das partículas de poeira suspensas no ar dos ambientes de trabalho. São Paulo: FUNDACENTRO; 2001.

Segurança e Medicina do Trabalho. Manuais de Legislação Atlas. 76. ed. São Paulo: Atlas; 2015. $1112 \mathrm{p}$.

Tatum VL, Ray AE, Rovell-Rixx DC. The performance of personal inhalable dust sampler in wood-products industry facilities. Appl Occup Environ Hyg. 2001;16(7):763-9. http://dx.doi.org/ 10.1080/10473220121612. PMid:11458924.

Teixeira RL. Fatores do ambiente de trabalho durante o corte de painéis de fibras de média densidade (MDF) em indústrias moveleiras [tese]. Lavras: Universidade Federal de Lavras; 2013.

Tremblay A, Badri A. A novel tool for evaluating occupational health and safety performance in small and medium-sized enterprises: the case of the Quebec forestry/pulp and paper industry. Saf Sci. 2018;101:282-94. http://dx.doi.org/10.1016/ j.ssci.2017.09.017.

Top Y, Adanur H, Öz M. Comparison of practices related to occupational health and safety in microscale wood-product enterprises. Saf Sci. 2016;82:374-81. http://dx.doi.org/10.1016/ j.ssci.2015.10.014.

Verma DK, Demers C, Shaw D, Verma P, Kurtz L, Finkelstein M, et al. Occupational exposure to chemical, biological, and physical agents in Ontario sawmill and veneer/plywood plants: a pilot study. Hamilton: McMasterUniversity; 2007. http://dx.doi.org/10.1155/2010/526487. 